\title{
Ochrana vod před dusičnany ze zemědělství
}

\begin{abstract}
ANNA HRABÁNKOVÁ
Klíčová slova: zranitelné oblasti - dusičnany - akční program - nitrátová směrnice
\end{abstract}

\section{SOUHRN}

Cílem směrnice Rady 91/676/EHS o ochraně vod před znečištěním způsobeném dusičnany ze zemědělských zdrojů [1] (dále "nitrátová směrnice") je snižovat znečištění vod, které pochází ze zemědělských zdrojů, a prèedcházet dalšímu takovému znečištování, a to jednak pro zajištění dodávek kvalitní pitné vody a jednak k ochraně povrchové vody pred eutrofizací. Transpozice nitrátové směrnice byla provedena ustanovením $§ 33$ zákona č. 254/2001 Sb., o vodách, ve znění pozdějších předpisů [2], kde je uloženo vládě nařízením stanovit zranitelné oblasti a v těchto oblastech upravit používání a skladování hnojiv a statkových hnojiv, stř̌́dání plodin a provádění protierozních opatření. Zranitelné oblasti byly v roce 2003 nařizením vlády č. 103/2003 Sb., o stanovení zranitelných oblastí a o používání a skladování hnojiv a statkových hnojiv, stříání plodin a provádění protierozních opatření v těchto oblastech [3], vymezeny výčtem katastrálních území, která leží v povodích povrchových vod a oblastech podzemních vod, kde bylo prokázáno významné znečištění dusičnany ze zemědělských zdrojů nebo kde okolnosti nasvědčují tomu, že může dojít k dalšímu zhoršení jakosti vod. Toto nařizení vlády zároveň stanovilo, že přezkoumání zranitelných oblastí a návrhy na změny jejich rozsahu musí být předloženy vládě nejpozději do čtyř let od prvního vymezení. V současné době jsou vyhlášeny zranitelné oblasti nařízením vlády č. 262/2012 Sb., o stanovení zranitelných oblastí a akčním programu v platném znění [4], které nahradilo původní nařízení vlády č. 103/2003 Sb.

\section{ÚVOD}

Znečištění vod dusičnany je závažný problém, který ohrožuje nejen člověka, ale také prírodu a krajinu. Rada Evropských společenství proto v roce 1991 konstatovala, že obsahy nitrátů ve vodách v určitých oblastech stoupají a dosahují hodnot, které jsou nepřiměřené vzhledem k limitům daných požadavky na jakost vod ve zdrojích používaných pro pitné účely a že tento vývoj není obecně $\checkmark$ souladu se zájmy ochrany prírodního prostředí vyjádřenými v jiných usneseních EHS. Rada ES proto přijala směrnici 91/676/EHS k ochraně vod před znečištěním dusičnany ze zemědělských zdrojů (nitrátová směrnice), která ukládá členským státům vymezit zranitelné oblasti a učinit potřebné kroky ke snížení tohoto znečištění.

Požadavky uvedené směrnice byly transponovány do českého vodního práva v $\$ 33$ zákona č. 254/2001 Sb., o vodách, ve znění pozdějších předpisů, kde je uloženo vládě nařizením stanovit zranitelné oblasti a v těchto oblastech upravit použivání a skladování hnojiv a statkových hnojiv, střídaní plodin a provádění protierozních opatření.

\section{POŽADAVKY SMĚRNICE RADY 91/676/EHS (NITRÁTOVÉ SMĚRNICE)}

Hlavním cílem nitrátové směrnice je snížit znečištění vod způsobené dusičnany ze zemědělských zdrojů a predcházet dalšímu takovému znečištění.

Pro splnění požadavků této směrnice bylo nutné provést pět následujících zásadních kroků:

— Stanovit znečištěné a ohrožené vody, vytvořit monitoring jakosti povrchových a podzemních vod a monitoring účinnosti akčního programu.

- Vymezit zranitelné oblasti, které představují území odvodňovaná do povrchových a podzemních vod znečištěných nebo ohrožených dusičnany ze zemědělských zdrojủ. Hlavním kvalitativním kritériem znečištění vod je koncentrace dusičnanů vyšší než 50 mg/l nebo taková koncentrace, která by mohla stanovenou hranici překročit, pokud by nebyla zavedena účinná opatření. Součástí posouzení je také určení míry eutrofizace povrchových vod. Vymezené zranitelné oblasti podléhají revizi nejpozději do 4 let od předchozího vymezení.

- Stanovit Zásady správné zemědělské praxe zaměěené na ochranu vod před znečištěním dusičnany ze zemědělských zdrojů (dále jen "Zásady"), které představují souhrn obecných požadavků jak hospodařit, aby nedocházelo k nadměrnému zatěžování veškerých vod dusičnany. Zásady jsou uplatňovány na dobrovolné bázi na celém území ČR. Pro tyto účely jsou pak připraveny školicí programy pro zemědělce.

- Sestavit, zavést a realizovat akční program, kontrolovat a vynucovat dodržování jeho jednotlivých opatření. Akční program představuje povinné zpưsoby hospodaření ve vymezených zranitelných oblastech, prǐčemž vychází z dostupných vědeckých a technických údajů a respektuje rozdílné půdní a klimatické podmínky zranitelných oblastí. Akční program musí obsahovat požadavky stanovené v nitrátové směrnici a opatření uvedená v Zásadách.

- Pro zranitelné oblasti se tak stávají příslušná opatření stanovená v Zásadách součástí akčního programu, jehož plnění je pro podnikatele hospodaříí v zemědělství povinné.

Součástí implementace nitrátové směrnice je také zajištění zpracování a odeslání povinných zpráv Evropské komisi o plnění nitrátové směrnice za každé čtyřleté období.

Zranitelné oblasti na území ČR a první akční program byly vyhlášeny nařízením vlády č. 103/2003 Sb., o stanovení zranitelných oblastí a o používání a skladování hnojiv a statkových hnojiv, střídání plodin a provádění protierozních opatření v těchto oblastech [3], s účinností od 11. dubna 2003, na základě zmocnění § 33 zákona č. 254/2001 Sb., o vodách. První akční program pro zranitelné oblasti České republiky byl vyhlášen k 1. 1. 2004, s termínem jeho zavedení do 31. 12. 2007. První revize vymezení zranitelných oblastí byla uplatněna novelou tohoto nařízení, a to nařízením vlády č. 219/2007 Sb., s účinností od 1. 9. 2007 [5]. Druhý akční program na období 2008-2011 byl vyhlášen novelou nařizení vlády č. 103/2003 Sb., a to nařízením vlády č. 108/2008 Sb., s účinností od 4. 4. 2008 [6]. Pưvodní předpis byl v roce 2012 zrušen novým nařizením vlády 
č. 262/2012 Sb., o stanovení zranitelných oblastí a akčním programu (dále jen „nařízení vlády") [4], které s účinností od 1. 8. 2012 vyhlásil druhou revizi zranitelných oblastí a vyhlásil 3. akční program. Třetí revize vymezení zranitelných oblastí byla uplatněna novelou č. 235/2016 Sb. tohoto nařízení s účinností od 1. 8. 2016 [7]. Čtvrtý akční program a jeho úpravy v této novele vycházely predevším z výsledků monitoringu realizace třetího akčního programu v zemědělské praxi, nových vědeckých poznatků a požadavků Evropské komise.

\section{VYMEZENÍ A REVIZE ZRANITELNÝCH OBLASTÍ}

\section{Vymezení zranitelných oblastí}

Jak již bylo výše konstatováno, první zranitelné oblasti byly vymezeny v roce 2002 [8]. Při vymezování zranitelných oblastí bylo nutné vyřešit, jak postupovat při vyhodnocování všech koncentrací podzemních a povrchových vod. Základním podkladem pro vymezování zranitelných oblastí povrchových vod bylo vymezení ověřených a neověřených oblastí v roce 1999 v projektu VaV 510/4/98 Omezování plošného znečištění povrchových a podzemních vod v ČR [9]. Tyto oblasti byly takto rozděleny na základě posouzení, zda se jedná o vodohospodářsky významnou oblast (povodí vodárenských nádrží), dále podle toho, jaké je riziko vyplavování dusičnanů vzhledem k bilančnímu přebytku dusičnanů př́tomných v pưdě, a samozřejmě hlavně na základě vyhodnocení výsledků dostupného monitoringu jakosti povrchových a podzemních vod a hodnocení projevů eutrofizace způsobené dusičnany. První hodnocení probíhalo zvlášt pro povrchové a zvlášt pro podzemní vody. Při posouzení zranitelných oblastí podzemních vod bylo potřeba identifikovat, jak se znečištěni dusičnany širíi v podzemních vodách a kde se projeví jeho účinky. Vycházelo se z prírodních podmínek útvarů podzemních vod. Podle vlastností hydrogeologické struktury je možné oběh podzemních vod rozdělit na dva případy. V prvním prípadě (útvary podzemní vody s jednoduchým oběhem) jde o oblasti s nesouvislým zvodněním (hlavně oblasti krystalinických hornin) nebo mělkým oběhem podzemní vody v připovrchové zóně (především kvartérní kolektory), znečištění podzemních vod se zde většinou bezprostředně objevuje i v povrchových vodách. $V$ těchto prípadech byly hodnoceny koncentrace $\mathrm{NO}_{3}$ společně $v$ povrchových i podzemních vodách. $V$ hydrogeologických rajonech se souvislým zvodněním (převážně v pánevních strukturách) je hlubší a složitější oběh podzemní vody. Podzemní a povrchová voda se zde tedy musí hodnotit zvlášt, protože absence znečištění v povrchových vodách v těchto oblastech automaticky nevylučuje znečištění podzemních vod. Celé území ČR bylo tedy rozděleno na dva typy oblastí podle prevažujícího typu oběhu podzemních $\operatorname{vod}$ (obr. 1).

Při rozhodování o zařazení plochy mezi zranitelné oblasti byly také použity podpůrné podklady, které umožnily odlišit původ znečištění, rozsah využití půdy $v$ jednotlivých oblastech, intenzitu zemědělského hospodaření a obecnou zranitelnost půd a horninového prostředí.

$\checkmark$ roce 2002 ještě nebyl zaveden speciální monitoring povrchových vod pro nitrátovou směrnici, pro hodnocení byla tedy využita všechna dostupná data z dosavadních prováděných monitoringů jakosti povrchových vod, zvláště z měření na drobných vodních tocích zajištovaných Státní meliorační správou (SMS) a také z probíhajícího měěení jakosti podzemních vod provozovaného Českým hydrometeorologickým ústavem (ČHMÚ). Pro hospodářskou bilanci dusíku byly použity statistické údaje Českého statistického úřadu (Čsú) a údaje z databáze Ministerstva zemědělství (MZe). Pro rozlišení jednotlivých ekosystémů byla využita vrstva CORINE - Land Cover pořízená z družicových snímků z období 1990-1992.

Výsledné zranitelné oblasti vymezené $v$ povodích 4. rádu byly po jejich homogenizaci převedeny z legislativně-administrativních důvodů na plochy

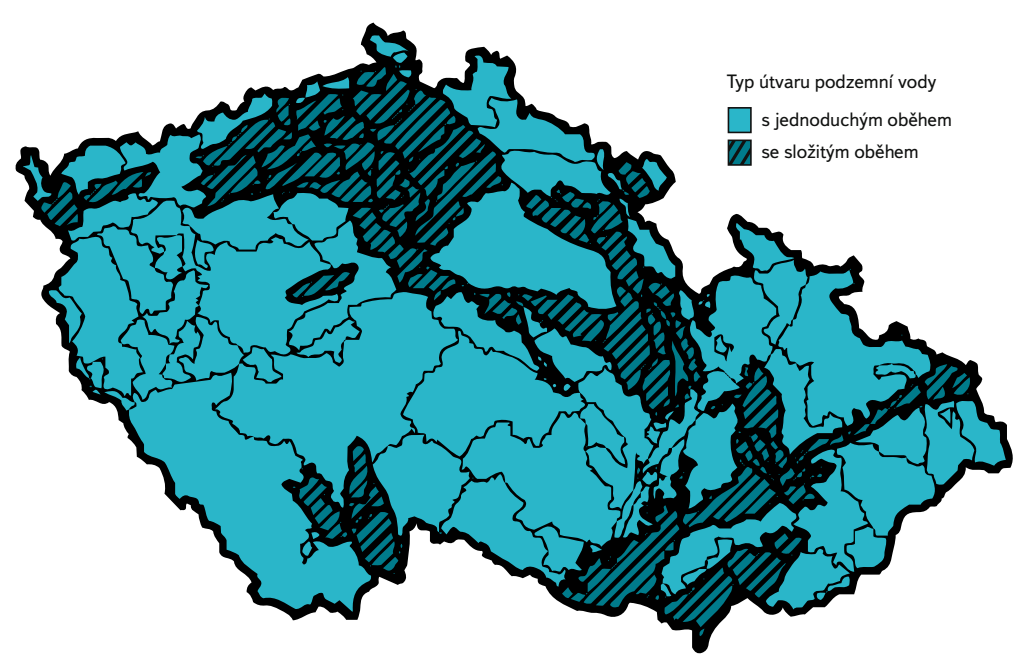

Obr. 1. Rozdělení území ČR podle vlastností hydrogeologické struktury útvarů podzemních vod

Fig. 1. Distribution of area of CR according to the hydrogeological structure

katastrálních území, které umožňují vlastníkovi nebo uživateli pozemku identifikovat, zda se nachází ve zranitelné oblasti, či nikoliv. Pro převod území na katastry byla stanovena pevná kritéria (plocha katastru je vice než ze 75 \% pokryta vymezeným zranitelným územím), aby nedocházelo k nežádoucímu rozšiřování vymezených území.

Zranitelné oblasti byly vymezeny na 36,7 \% území České republiky.

\section{REVIZE ZRANITELNÝCH OBLASTÍ}

Podle nitrátové směrnice musí probíhat pravidelné přezkoumání vymezení zranitelných oblastí do 4 let od jejího vymezení. V České republice tak proběhly již 3 revize, v letech 2007 [10], 2011 [11] a v roce 2015 [12]. Při návrhu revidovaného vymezení se vychází z predpokladu, že pokud mají být opatření akčních programů účinná a tím zajištěna ochrana vod, je nutné v každém období mezi jednotlivými revizemi zaměřit pozornost na skutečně problémové oblasti a $v$ nich aplikovat co nejúčinnější opatření, která povedou ke zlepšení stavu. Vyplývá to ze smyslu nitrátové směrnice, jejímž účelem je cílené snižování znečištění vod pomocí přísnějších požadavků v jasně definovaných oblastech. Proto Česká republika přistoupila k možnosti, že v rámci revizí budou vyhodnocena aktuální data z jakosti povrchových a podzemních vod a současně také jejich trendy, a podle těchto výsledků bude rozhodnuto bud' o rozšírení plochy zranitelných oblastí, nebo v prípadě výrazného zlepšení stavu také o jejich zrušení. Týká se to prípadů, kde koncentrace dusičnanů za predchozí období byly pod hranicí $25 \mathrm{mg} / \mathrm{l}$ a trend jejich vývoje byl klesající. V tomto případě je předpokládáno, že dostatečnou ochranu území již zajistí běžné nástroje (např. Zásady správné zemědělské praxe). Tato metodika byla použita ve všech třech provedených revizích.

Od roku 2002, kdy byly zranitelné oblasti vymezeny, došlo k výraznému posunu ve vývoji v oblasti datových podkladů i ke zpřesnění způsobu hodnocení. I nadále jsou pro revize používána data ČHMú o jakosti povrchových i podzemních vod. Výraznou pomocí pro zkvalitnění podkladů pro jednotlivé revize bylo navržení nového optimalizovaného monitoringu drobných vodních toků, který navazoval na sít provozovanou Státní meliorační správou od roku 1993 a poté její nástupnickou organizací Zemědělskou vodohospodářskou správou. Tento monitoring je cíleně situován pro potřeby nitrátové směrnice a zároveň je převážná část profilů umístěna v místech reprezentativních pro monitorování vodních útvarů podle Rámcové směrnice 2000/60/ES [13]. Monitorovací 


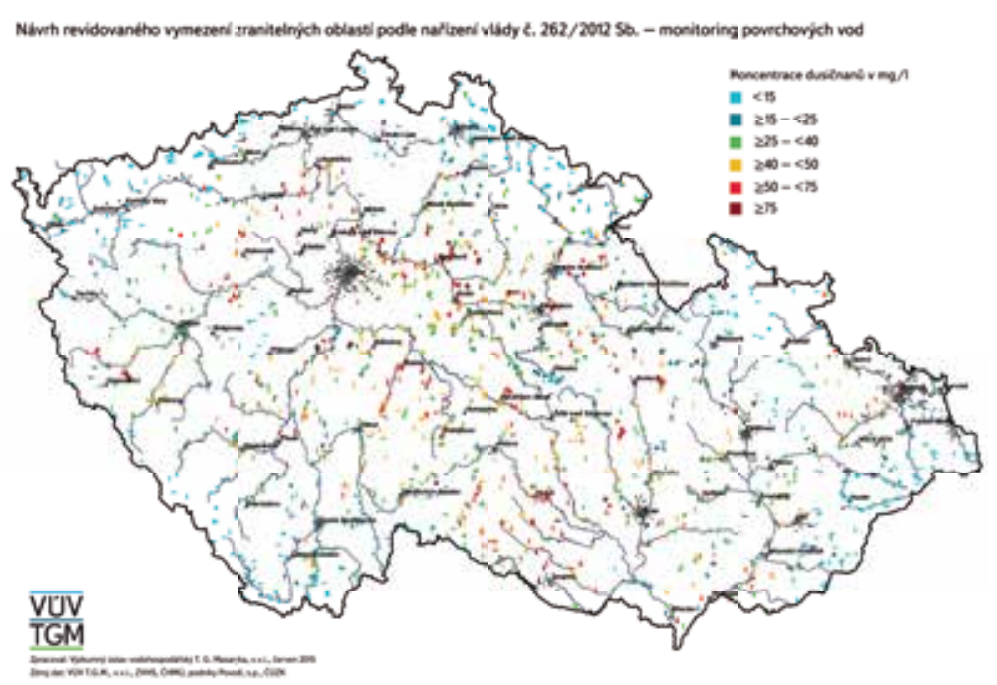

Obr. 2. Vyhodnocení monitoringu povrchových vod

Fig. 2. Assessment of the nitrate concentrations in surface water

sît se skládá z hlavních profilů, které jsou měřeny dlouhodobě každý měsíc a jsou situovány právě $v$ místech reprezentativních pro monitorování vodních útvarů. Další součástí jsou vedlejší profily, které jsou sledovány 12× za rok a jsou rozděleny do čtyř skupin tak, aby byly měřeny v pravidelných 4letých cyklech. Výsledky těchto sledování jsou jedním ze základních podkladů pro revize zranitelných oblastí. Od zavedení této monitorovací sítě proběhlo několik jejích optimalizací a $\vee$ současné době je provozována podniky Povodí podle jejich územní príslušnosti, výsledky pak spravuje Povodí Moravy, s. p.

Díky projektu Technologické agentury České republiky TA01010670 Chráněná území povrchových a podzemních vod pro lidskou spotřebu - hodnocení jakosti surové vody a jeho využití v praxi [14] bylo možné ve větší míře použít pro hodnocení jakosti také data o jakosti surové vody určené pro lidskou spotřebu pořizovaná na základě zákona č. 274/2001 Sb., o vodovodech a kanalizacích pro veřejnou potřebu [15] a jeho prováděcí vyhlášky č. 428/2001 Sb. [16]. Jedná se o výsledky

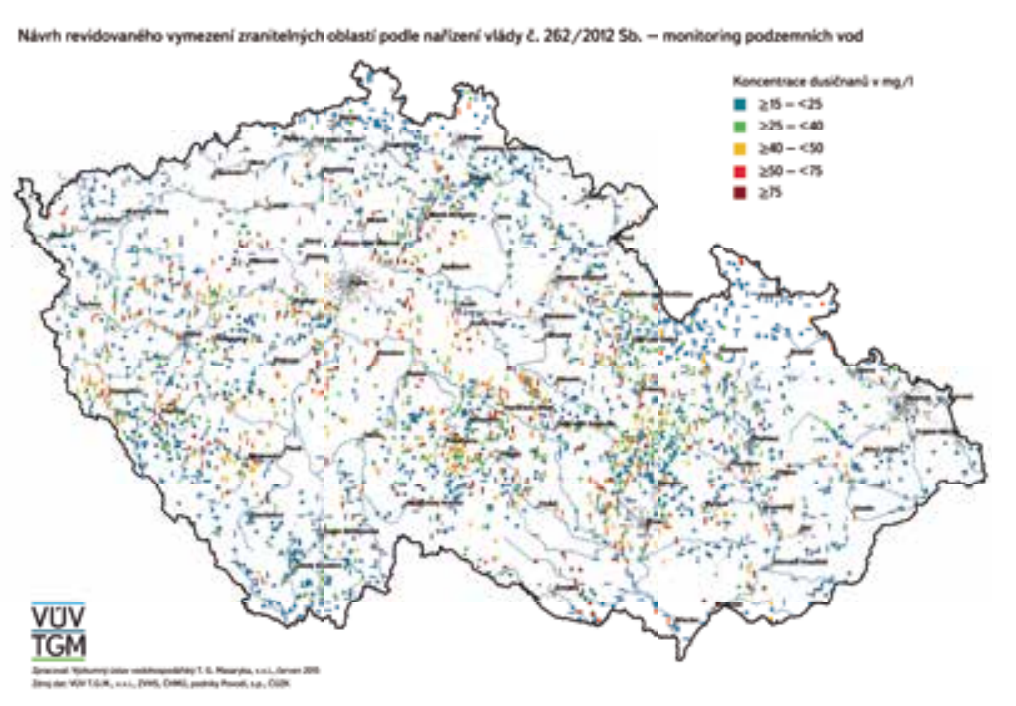

Obr. 3. Vyhodnocení monitoringu podzemních vod

Fig. 3. Assessment of the nitrate concentrations in groundwater

měření jakosti provozovatelů vodovodů, kteří tato data $v$ současnosti pravidelně zasílají podnikům Povodí a krajským úřadům (dříve Ministerstvu zemědělství). Tyto údaje byly vzhledem ke způsobu jejich vykazování pro hromadné vyhodnocení nedostupné, díky řešenému projektu vznikla ve VúV TGM databáze, kterou bylo možno využít jako zásadní podklad pro hodnocení jakosti zvláště podzemních vod.

Na následujících obrázcích (obr. 2 a 3) je ukázka výsledků hodnocení jakosti povrchových a podzemních vod pro revize $v$ roce 2015. Jednotlivá monitorovací místa jsou vyhodnocena a rozdělena do kategorií podle hodnoty koncentrací $\mathrm{NO}_{3}$. Pokud to bylo možné z hlediska časových řad měření, u každého místa byl vyhodnocen také trend: vzrůstající (šipka směrem nahoru), klesající (šipka dolů) a stabilní (vodorovná šipka). Kde nebylo možné hodnotit trend vzhledem k počtu měření, je toto místo vyznačeno pouze jako bod.

Tabulka 1. Tabulka ploch vymezených zranitelných oblastí

Table 1. Table of areas of defined vulnerable areas

\begin{tabular}{llll}
$\begin{array}{l}\text { Vymezení } \\
\text { v roce } \mathbf{2 0 0 3}\end{array}$ & $\begin{array}{l}\text { 1. revize vymezení } \\
\text { v roce } \mathbf{2 0 0 7}\end{array}$ & $\begin{array}{l}\text { 2. revize vymezení } \\
\text { v roce } \mathbf{2 0 1 1}\end{array}$ & $\begin{array}{l}\text { 3. revize vymezení } \\
\text { v roce } \mathbf{2 0 1 5}\end{array}$ \\
\hline 36,7 & 39,9 & 41,6 & 41,9
\end{tabular}

Podíl plochy zranitelných
oblastí v ploše ČR (v \%)

Podíl zemědělské pưdy *) ve

zranitelných oblastech $\mathrm{k}$ celkové

ploše zemědělské půdy v ČR (v \%)

\section{Podíl plochy zemědělské}

půdy *) z celkové plochy

42,5

47,7

49,0

50,2

zranitelných oblastí (v \%)
69,3

$69,3 \quad 68,4$

58,0
57,0

plochy zranitelných oblastí (v \%) 


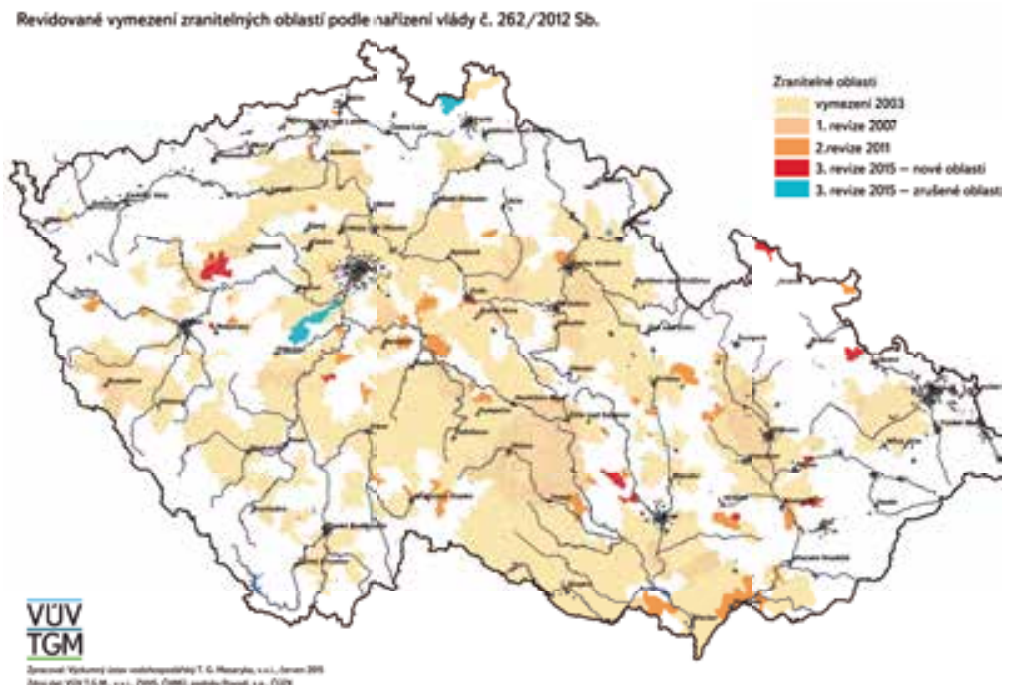

Obr. 4. Návrh revidovaného vymezení zranitelných oblastí

Fig. 4. Proposal for revision of the designation of vulnerable zones

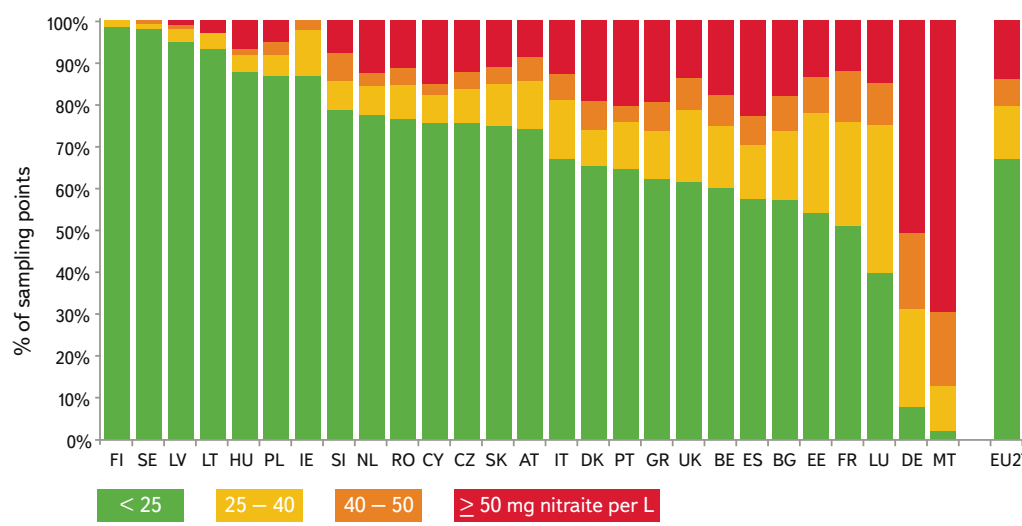

Obr. 5. Průměrné koncentrace dusičnanů v podzemních vodách podle členských států EU Fig. 5. Frequency diagram of groundwater classes (annual average nitrate concentrations in EU member states)

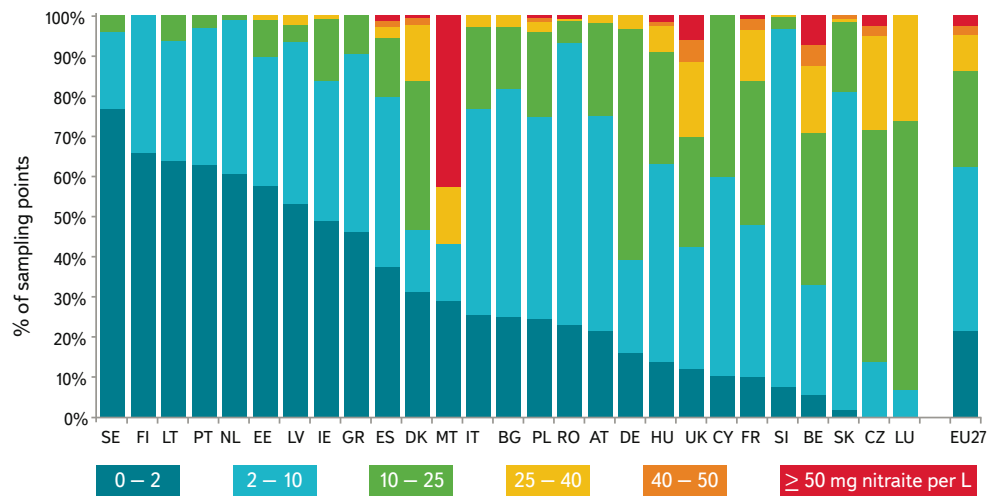

Obr. 6. Průměrné koncentrace dusičnanů v povrchových vodách podle členských států EU Fig. 6. Frequency diagram of average nitrate concentrations in fresh surface water classes (annual average nitrate concentrations in EU member states)
Další výraznou změnou při revizích zranitelných oblastí bylo vytvoření metodiky pro hodnocení eutrofizace [17]. Hodnocení je založeno v prvním kroku na vyhodnocení koncentrací dusičnanů, pokud koncentrace přesahuje $25 \mathrm{mg} / \mathrm{l}$, jsou tyto profily dále vyhodnocovány z hlediska celkového fosforu. U profilů, které jsou na základě tohoto posouzení hodnoceny $v$ horším než $v$ dobrém stavu, dochází k dalšímu kroku - určení míry vlivu zemědělského hospodaření na základě podílu dusičnanového dusíku na celkovém anorganickém dusíku ve vzorku. Na základě hodnoty tohoto poměru a podílu zastoupení zemědělských půd v povodí je toto povodí označeno jako zranitelné/nezranitelné z hlediska eutrofizace vod.

Výsledné revize zranitelných oblastí vycházejí v řešeném období z aktuálních vrstev katastrálních území a aktuálních výsledků leteckého snímkování CORINE Land Cover.

V tabulce 1 a obr. 4 je zaznamenán vývoj rozsahu zranitelných oblastí v celém období implementace nitrátové směrnice v období 2002-2015.

\section{PŘEDKLÁDÁNÍ NÁRODNÍCH ZPRÁV O PLNĚNÍ NITRÁTOVÉ SMĚRNICE}

Součástí implementace nitrátové směrnice je také zajištění zpracování a odeslání povinných zpráv Evropské komisi o plnění nitrátové směrnice za každé čtyřleté období. Reportingová zpráva je odesílána každým členským státem $\checkmark$ předepsaném formátu a obsahuje vyhodnocení a statistické údaje za předepsané období. Jedná se o údaje z oblasti monitoringu vod a plnění akčního programu, nedílnou součástí zprávy je také výhled vývoje znečištění vod z hlediska účinnosti nastavených opatření pro zlepšení její jakosti.

Evropská komise pak na základě jednotlivých národních zpráv vyhotoví celoevropskou zprávu a statistiky o účinnosti nitrátové směrnice a následně pak z těchto výsledků čerpá nové poznatky o možných potřebných důrazech, napřiklad $v$ oblasti nastavení akčních programů pro zemědělce. Ze statistik vyplývá, že Česká republika se nachází z hlediska rozlohy zranitelných oblastí $\checkmark$ evropském průměru (samozřejmě zde nejsou započteny státy, které se rozhodly stanovit zranitelné oblasti celoplošně). Zajímavé je i srovnání výsledků monitoringu dusičnanů v ostatních státech. Nová evropská zpráva bude vytvorena na začátku roku 2017, uvádíme tedy pro informaci ukázku z poslední evropské společné zprávy z roku 2012 (obr. 5-7). 


\section{VÝSLEDKY A DISKUSE}

Hlavním cílem nitrátové směrnice je chránit jakost vod v členských státech Evropské unie pomocí předcházení úniků dusičnanů ze zemědělských zdrojů do podzemních a povrchových vod. Ukazuje se, že opatření, která jsou nastavena pomocí jednotlivých akčních programů, a prosazování správné zemědělské praxe někde přinášejí své výsledky v podobě snižování znečištění zdrojů vod. Je patrné, jak nezbytné jsou kvalitní monitorovací programy a jejich vzájemná provázanost s vyhodnocováním účinnosti akčního programu a úzká spolupráce se zemědělci. Opatření akčního programu jsou každé 4leté období revidována a stále zpř́isňována, ať už se jedná o období zákazu hnojení, limitů povolených dávek a způsobu hospodaření. Je nutné si ale uvědomit, že celý proces zlepšení jakosti vod má dlouhodobý charakter, a tak výsledky jsou zatím pouze pozvolné. Dílčí zlepšení je možné pozorovat napríklad v oblastech, které mohly být v roce 2015 vypuštěny ze seznamu zranitelných oblastí, na druhou stranu ve výsledku došlo k opětovnému navýšení plochy zranitelných oblastí a z hodnocení trendů a tím také budoucího vývoje znečištění nevyplývá možnost zásadního zmenšení jejich rozsahu.

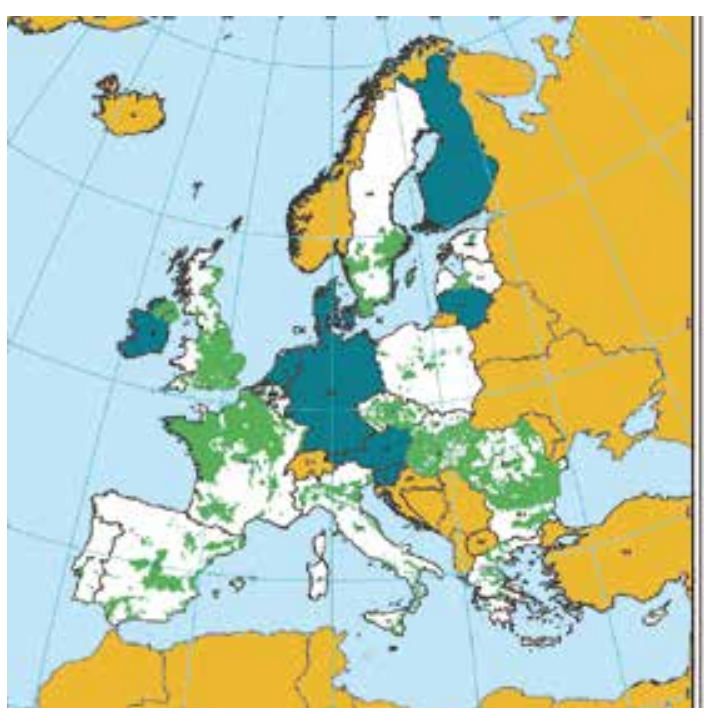

Nitrates Directive $[91 / 676 /$ EEC $]$

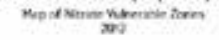

NVZ nocus
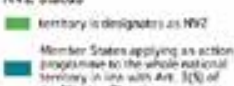

$\square$ ㄴ.

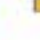

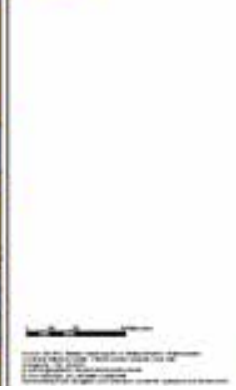

Obr. 7. Zranitelné oblasti v roce 2012; zeleně jsou uvedeny vymezené zranitelné oblasti; modrou barvou jsou vyznačena území států, které se rozhodly uvažovat celé území jako zranitelné; oranžovou barvu mají území mimo Evropskou unii

Fig. 7. Vulnerable zones in 2012

\section{Literatura}

[1] CEC. Council Directive of 12 December 1991 concerning the protection of waters against pollution caused by nitrates from agricultural sources, 91/676/EEC. Official Journal No L 375, 31. 12. 1991, p. 1

[2] Zákon č. 254/2001, ze dne 28. června 2001, o vodách a o změně některých zákonů ve znění pozdějších predpisů.

[3] Nařízení vlády č. 103/2003, ze dne 3. brezna 2003, o stanovení zranitelných oblastí a o používání a skladování hnojiv a statkových hnojiv, střídání plodin a provádění protierozních opatření v těchto oblastech.

[4] Nařízení vlády č. 262/2012, ze dne 4. července 2012, o stanovení zranitelných oblastí a akčním programu.

[5] Nařizení vlády č. 219/2007, ze dne 11. července 2007, kterým se mění nařízení vlády č. 103/2003 Sb., o stanovení zranitelných oblastía o použivání a skladování hnojiv a statkových hnojiv, střídání plodin a provádění protierozních opatření v těchto oblastech.

[6] Nařizení vlády č. 108/2008, ze dne 25. února 2008, kterým se mění nařízení vlády č. 103/2003 Sb., o stanovení zranitelných oblastí a o použivání a skladování hnojiv a statkových hnojiv, střídání plodin a provádění protierozních opatření v těchto oblastech

[7] Nařízení vlády č. 235/2016, ze dne 27. července 2016, o stanovení zranitelných oblastí a akčním programu.

[8] HRABÁNKOVÁ, A., ROSENDORF, P. a PRCHALOVÁ, H. Návrh vymezení zranitelných oblastí. Závěrečnà zpráva úkolu č. 1320. Praha: VÚV TGM, 2002.

[9] ROSENDORF, P. ed. Omezování plošného znečištěni povrchových a podzemních vodv $v$ ČR, projekt Rady vlády ČR pro výzkum a vývoj VaV/510/4/98, souhrnná závěrečná zpráva za období řešení 1998-2002, 2003, 271 s.

[10] HRABÁNKOVÁ, A. aj. Revize zranitelných oblastí pro nitrátovou směrnici. Návrh revidovaného vymezení zranitelných oblastípodle nařizenívlády č. 103/2003 Sb. Závěrečná zpráva úkolu č. 3733. Praha: VúV TGM, 2007.

[11] HRABÁNKOVÁ, A. aj. Návrh revidovaného vymezení zranitelných oblastí podle nar̆izení vlády č. 103/2003 Sb. Závěrečná zpráva úkolu č. 3733. Praha: VÚV TGM, 2011.

[12] HRABÁNKOVÁ, A. aj. Návrh revidovaného vymezeni zranitelných oblastí podle nařizení vlády č. 262/2012 Sb. Závěrečná zpráva úkolu č. 3701. 06. Praha: VúV TGM, 2015.

[13] EC. Směrnice 2000/60/ES Evropského parlamentu a Rady z 23. ř́jna 2000 ustavující rámec pro činnost Společenství v oblasti vodní politiky. Aktualizovaný pracovní překlad s anglickým originálem. Úplné znění, zahrnující text Přilohy X. (Rozhodnutí č. 2455/2001/ES Evropského parlamentu a Rady ze dne 20. listopadu 2001 ustavující seznam prioritních látek v oblasti vodní politiky a pozměňující směrnici 2000/60/ES). Praha, Ministerstvo životního prostředí, odbor ochrany vod, srpen 2003, 98 s.

[14] HRABÁNKOVÁ, A. aj. TA01010670 "Chráněná územi povrchových a podzemních vod pro lidskou spotřebu - hodnoceníjakosti surové vody a jeho využití v praxi", 2011-2013.

[15] Zákon č. 274/2001 Sb., ze dne 10. července 2001, o vodovodech a kanalizacích pro veřejnou potřebu a o změně některých zákonů (zákon o vodovodech a kanalizacích).

[16] Vyhláška č. 428/2001 Sb., ze dne 16. listopadu 2001, kterou se provádí zákon o vodovodech a kanalizacích pro veřejnou potřebu a o změně některých zákonů (zákon o vodovodech a kanalizacích).

[17] ROSENDORF, P. a FIALA, D. Metodika vymezování zranitelných oblastí podle eutrofizace vod pro potřeby implementace smërnice Rady 91/676/EHS o ochraně vod před znečištěním zpuisobeném dusičnany ze zemédělských zdrojů. Certifikovaná Metodika VúV TGM, v. v. i., Výzkumný záměr MZP0002071101, subprojekt 3617, Praha: Vúv TGM, v. v. i., 2011, s. 51. 


\section{Poděkování}

Přispěvek vznikl na základě dlouhodobé činnosti podporované Ministerstvem život ního prostředi a také díky práci mnoha kolegů z VÚV TGM, v. v. i., kteři se na implementaci nitrátové směrnice podíleli.

\section{Autoři}

Ing. Anna Hrabánková

凶anna_hrabankova@vuv.cz

Výzkumný ústav vodohospodáš̌ský T. G. Masaryka, v. v. i.

Příspěvěk prošel lektorským řízením.

\section{WATER PROTECTION AGAINST NITRATES FROM AGRICULTURE}

\section{HRABANKOVA, A.}

TGM Water Research Institute, p. r. i.

Keywords: vulnerable zones - nitrate - action

programme - Nitrates Directive

The aim of Council Directive 91/176/EEC regarding the protection of waters against pollution caused by nitrates from agricultural sources [1] (hereinafter "Nitrates Directive") is to reduce water pollution coming from agricultural sources and to prevent further such pollutions in order both to provide good-quality water supplies and to protect surface water against eutrophication. Transposition of the Nitrates Directive was carried out by provision Section 33 of Act No. 254/2001 Coll., on waters, as amended [2], where it is required that in the Regulation the Government stipulates vulnerable zones and arranges use and storage of fertilisers and livestock manure, rotation of crops and implementation of anti-erosion measures within these zones. Vulnerable zones are designated in this Government Regulation No. 103/2003 Coll., of March 3, 2003 on stipulation of vulnerable zones and on the use and storage of fertilizers and barnyard fertilizers, alternation of crops and implementation of anti-erosion measures through a list of cadastral territories that are located in river basins of surface waters and in groundwater areas where substantial nitrate pollution from agricultural sources has been demonstrated or where circumstances indicate that further deterioration in water quality can occur. This Government Regulation in these zones further stated that revision of vulnerable zones and proposals concerning changes of their extent have to be submitted to the Government at least no later than four years after the first designation.

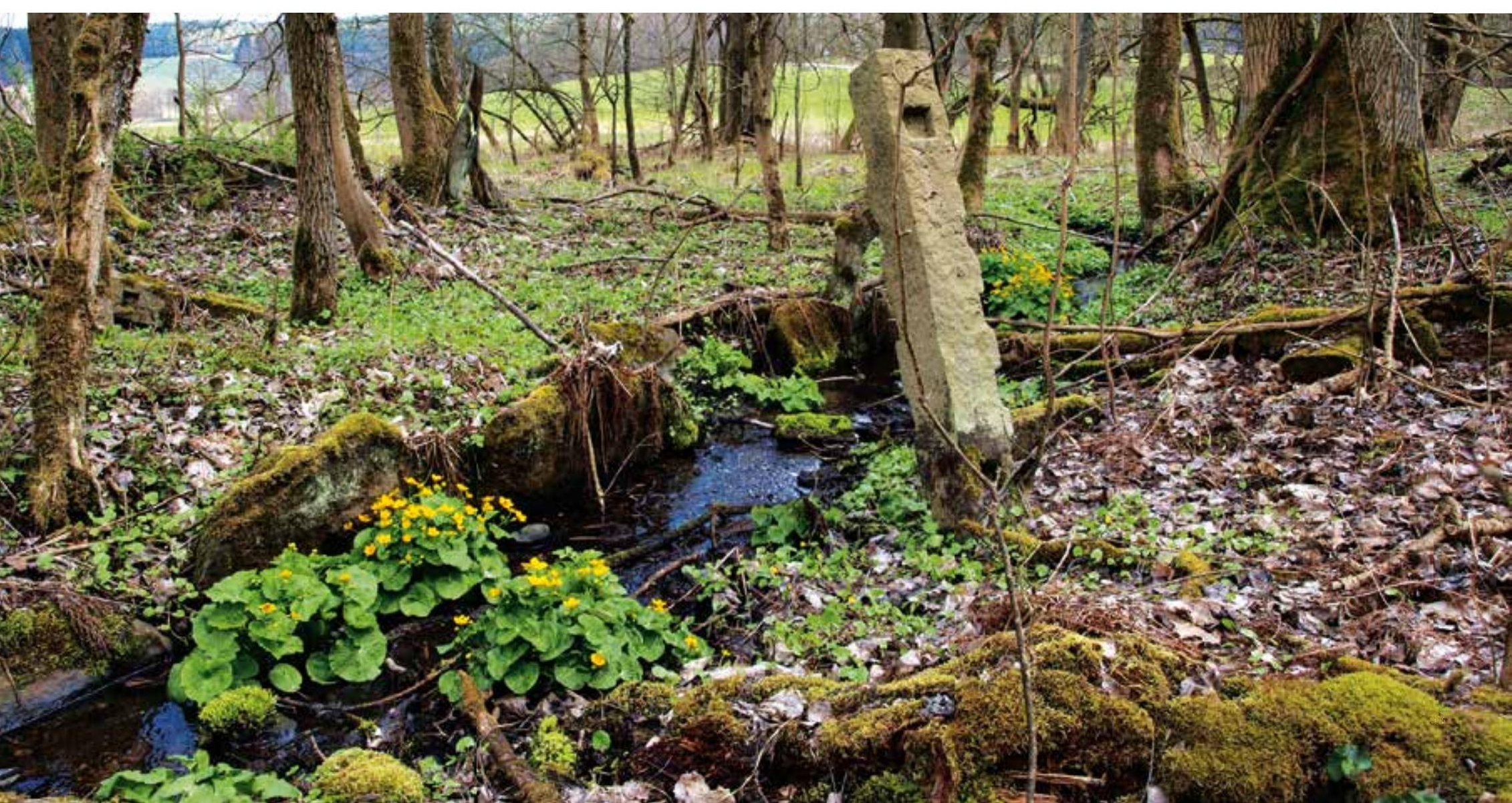

